\title{
To Explore the Effectiveness of Computer Games to Improve Junior Primary Students in Drawing
}

\author{
Chun Wai Andy Fan
}

\begin{abstract}
Developing children as successful learners are the pivotal aim for teachers. Today, much of the content that needs to be learned by students is not intrinsically motivated to them. This paper presents quantitative results from a 6 week study in which two classes of six year olds primary students were using two different teaching methods: game based learning and traditional methods. The result found that the class with game based learning performed better than traditional method.
\end{abstract}

Index Terms-Classroom practice, game based learning, game design.

\section{INTRODUCTION}

Today, much of the content that needs to be learned by students is not intrinsically motivated to them - many students complaint learning is "boring," or sometimes the words such as "dry" and "dull" often come from their mouth. It is probably safe to say that today's teachers, trainers, and educators are rarely as effective as they might be in the motivating students, and this often causes real problems in getting our students to learn.

The contemporary video and computer games have become a $\$ 30$ billion worldwide industry. The rise is incredibly rapid over the past 30 years. Modern video and computer games offer a rich landscape of adventure and challenge that appeal to a growing number of people. Games are intrinsic motivated. These games capture and hold the attention of players for hours as they struggle to overcome the challenges created by the game designers

Is it possible for using computer games to facilitate students' learning? However, computer games have been criticized as being mindless entertainment with no educational value or content. Therefore, most parents think that playing games can hinder their kids' learning. In recent research, Gee [1], [2] and others argue that computer games have the potential to transform learning [1]-[4]. Moreover, research show that computer games function as pedagogical tools that create active, interested and critical learners [1]-[4]. Gee [1], [2] posits that computer games teach us about the learning process in ways that the traditional classroom environment does not. Furthermore, the U.S. military has greatly accelerated its investment in the use of simulations and games to both enhance and expand training capabilities [5]. While playing with the games, people acquire new

Manuscript received September 15, 2013; revised December 15, 2013 This work was supported by University of Macau. Specially thanks to a number of Pre-primary teachers and students to facilitate the research work in the school.

Chun Wai Andy Fan is with the University of Macau, Macau, China (e-mail: andyfan@umac.mo). knowledge and complex skills. Gaming could help address one of the nation's most pressing needs-strengthening our system of education. In addition, today's students who have grown-up with digital technology are especially poised to take advantage of educational games [6].

One particular pedagogical strategy stresses "learning by doing" as a means for developing in depth knowledge of specific domain (e.g. mathematics), rather than reading about concepts and expecting students to spontaneously develop deep knowledge [7]. Students begin to master domain specific concepts, progressing from novice to intermediate level, when they participate in situated learning activities. Games transform the learning process from being a passive task to one in which individuals engage in the experience of learning. Computer games supply authentic environments for learning, complete with high opportunities for students to develop and test their knowledge.

We believe that learning can be achieved through gaming, teaching much of the "boring" learning content in the classroom can be facilitated or replaced by computer games. However, there are few empirical studies that have examined the use of games within classrooms settings [8], [9]. Can the learning occur in the virtual world can be transferred to learning in the real world. Therefore, we explore the application of computer games as a learning tool.

\section{LITERATURE REVIEW}

In each decade since the advent of digital games, researchers have published dozens of essays, articles, and mainstream books on the power of game learning. These include, Marc Prensky's Digital Game-Based Learning [4], James Paul Gee's What Video Games Have to Teach Us about Learning and Literacy [1], Clark Aldrich's Simulations and the Future of Learning: An Innovative (and Perhaps Revolutionary) Approach to e-Learning [10], Steven Johnson's Everything Bad Is Good for You: How Today's Popular Culture Is Actually Making Us Smarter [11]. Many studies indicate that making games is motivating, bolsters esteem, and develops storytelling and other technical skills [12]-[18].

\section{OBJeCTIVES}

The aim of this study is to explore the effectiveness of using games to improve learning. More specifically, this research is trying to find out the answers of the following research questions:

1) To identify whether students can acquire and/or increase in their learning skills in a subject domain as a result of 
playing games relative to those students who use traditional style of learning?

2) To identify what characteristics of learning content can be better benefit from games.

\section{RESEARCH PLAN AND DESIGN}

This research was to study the effectiveness for primary 2 students on learning the use of Microsoft "Paint" through computer games. A quasi-experimental method was applied. Pre-test and post-test were conducted to evaluate the effectiveness of games. The experimental group used computer game for students to recognize the functions of various drawing tools in "Paint" while the control group based on teacher demonstration and with the assistance of the computers. Each group had 35 students

The study took 6 lessons to complete (once every week). Each lesson took 40 minutes. Week one were for the pre-test, week 2-4 week for the intervention, week 5 were for students to practice with "Paint" while the last week was for the post tests.

The intervention of the experimental group allowed students to play with the "Game" (see Fig. 1) which provided by the textbook "The genesis of computer science, the 2 nd edition-2". The game provided interactive graphics and sounds. It had few different levels, the first level required students to recognize the drawing tool. Higher levels required students to collect different drawing tools in order to complete the shape with different level of difficulty. Scores were given to all the correct actions that students performed. The screen dump of the game could be found as follows.

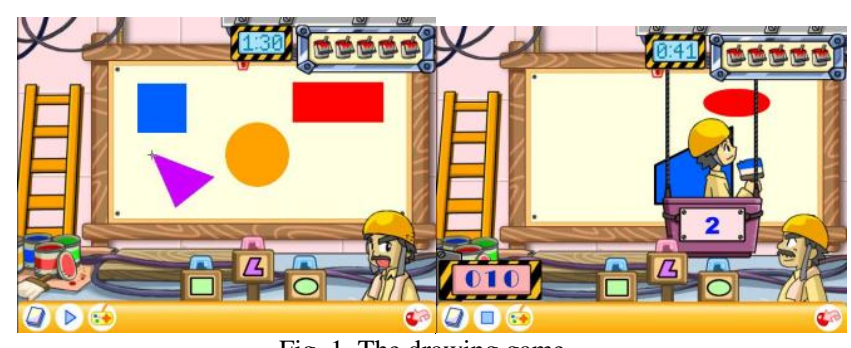

Fig. 1. The drawing game.
The intervention of the control group had a human teacher to demonstrate the characteristics of the drawing tools. Students were required to practice it in front of the computer. Finally the teacher required students to draw the shapes which were the same as those provided by the game.

\section{TEST PAPER}

Before the lessons, all students took a test paper (see figure 2). Within four 40 minutes typing lessons, the two groups took different approaches to learn the drawing tools. After finished all the lessons, the students took the test papers again to test their performance after the lessons. The effect of different approaches was evaluated through the comparison of the result of the pre and post tests.

The students were required to use "Paint" to draw a picture. The evaluation was based on whether the students can apply the following 10 items in drawing the picture. Each item carried 10 marks.

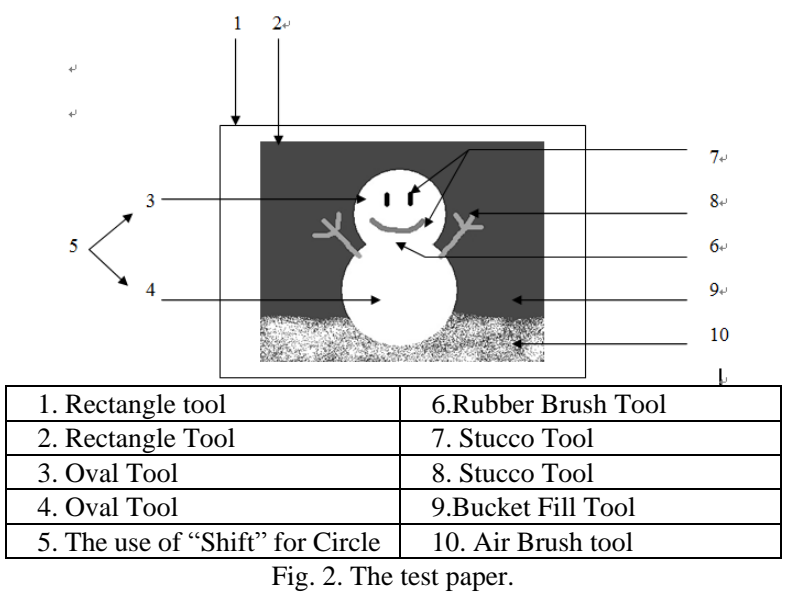

\section{RESULTS}

\section{A. Pre and Post Tests}

$T$-test was used to evaluate the significance of the intervention between pre and post tests.

TABLE I: T TEST RESULT FOR THE EXPERIMENTAL GROUP BETWEEN PRE AND POST TESTS

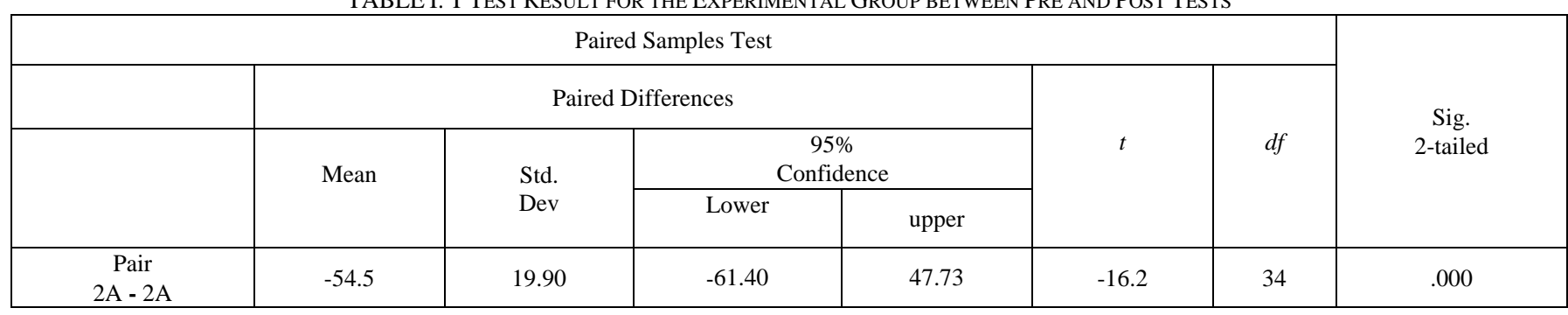

TABLE II: T TEST RESUlt FOR THE CONTROL GROUP BETWEEN PRE AND POST TESTS

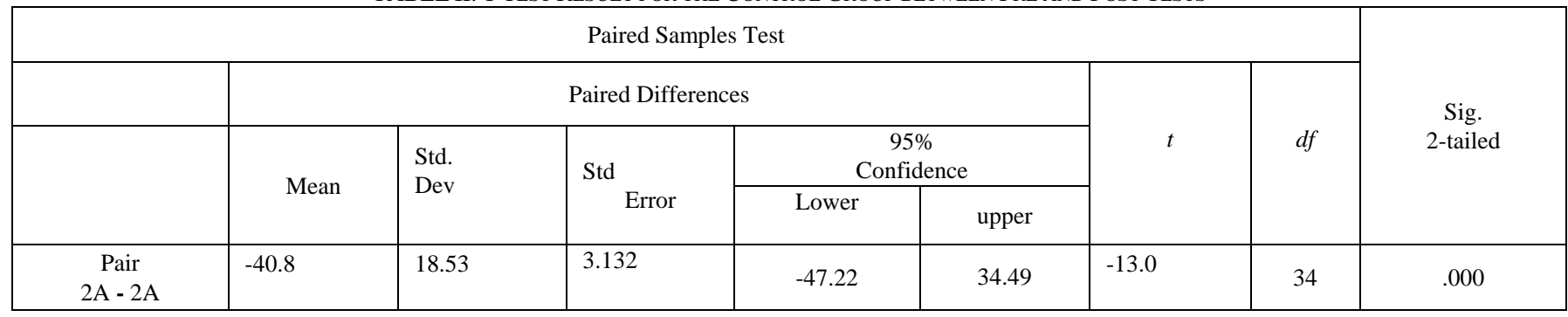


TABLE III: COMPARE THE PRE-TEST AND POST-TEST RESULTS FOR EXPERIMENTAL AND CONTROL GROUPS

INDEPENDENT SAMPLES TEST

\begin{tabular}{|c|l|l|}
\hline \multirow{2}{*}{\begin{tabular}{c} 
Pre Test 2AB \\
\cline { 2 - 3 } $\begin{array}{c}\text { (a)Equal variances assumed } \\
\text { (b) Equal variances not assumed }\end{array}$
\end{tabular}} & Levene's Test for Equality of Variances \\
\hline $\begin{array}{c}\text { Post Test 2AB } \\
\text { (a) Equal variances assumed } \\
\text { (b) Equal variances not assumed }\end{array}$ & 10.499 & Sig \\
\hline
\end{tabular}

\begin{tabular}{|c|c|c|c|c|c|c|c|}
\hline & \multicolumn{7}{|c|}{$t$-test for Equality of Means } \\
\hline & \multirow[t]{2}{*}{$t$} & \multirow[t]{2}{*}{$d f$} & \multirow{2}{*}{$\begin{array}{l}\text { Sig. } \\
\text { (2- } \\
\text { tailed) }\end{array}$} & \multirow[t]{2}{*}{$\begin{array}{l}\text { Mean } \\
\text { Diff }\end{array}$} & \multirow{2}{*}{$\begin{array}{l}\text { Std. } \\
\text { Err } \\
\text { Diff }\end{array}$} & \multicolumn{2}{|c|}{$\begin{array}{l}95 \% \text { Confidence } \\
\text { Interval }\end{array}$} \\
\hline & & & & & & Low & Up \\
\hline PreTest & & & & & & & \\
\hline $2 \mathrm{AB}$ & .91 & 68 & .36 & 3.71 & 4.0 & -4.4 & 11.8 \\
\hline $\begin{array}{l}\text { (a) } \\
\text { (b) }\end{array}$ & .91 & 67.76 & .36 & 3.71 & 4.0 & -4.4 & 11.8 \\
\hline PostTest & & & & & & & \\
\hline $2 \mathrm{AB}$ & 4.4 & 68 & .00 & 17.4 & 3.9 & 9.5 & 25.2 \\
\hline $\begin{array}{l}\text { (a) } \\
\text { (b) }\end{array}$ & 4.4 & 51.3 & .00 & 17.4 & 3.9 & 9.5 & 25.3 \\
\hline
\end{tabular}

TABLE IV: DIFFERENCE IN MEAN SCORE IN PRETEST AND POST-TEST FOR EXPERIMENTAL AND CONTROL GROUP

\begin{tabular}{|c|c|c|}
\hline Category & $\begin{array}{c}\text { Experimental } \\
\text { group }\end{array}$ & $\begin{array}{c}\text { Control } \\
\text { Group }\end{array}$ \\
\hline $\begin{array}{c}\text { Pre-Test Mean } \\
\text { (SD) }\end{array}$ & $38.57(17.51)$ & $\begin{array}{c}34.86 \\
(16.52)\end{array}$ \\
\hline $\begin{array}{c}\text { Post-Test Mean } \\
\text { (SD) }\end{array}$ & $93.14(10.78)$ & $2)^{75.71(20.6}$ \\
\hline Mean Difference & 54.57 & 40.85 \\
\hline
\end{tabular}

Table I showed the $T$ test result of the experimental group in pre and post tests. The value of $\mathrm{P}$ is lower than 0.05 . This demonstrated that the game learning had a positive effect on the scores. Table II showed the $T$ test result of the control group in pre and post tests. The value of $\mathrm{P}$ is lower than 0.05. This demonstrated that the traditional learning style had a positive effect on the scores. Table III compared the pre and post tests results for experiment and control groups. For pre-test, the value of $P$ was 0.542 which was higher than 0.05 . This implied there was no significant difference in pre-tests score between experimental and control groups. For post-test, the value of $P$ was 0.002 which was lower than 0.05 . This implied there was significant difference in post-tests score between experimental and control groups.

From Table IV, the Pre-test mean score for experimental and control group were 38.57 and 34.86 respectively. Experimental group was slightly highly control group for 3.71 marks. The Post-test mean score for experimental and control group were 93.14 and 75.71 respectively. Experimental group was higher than control group for 17.43 marks. Fig. 3 showed the difference between experimental group and control for the pre and post tests results.

Based on the above results, it was concluded that the Post-test for both experimental and control were significantly higher than Pre-test whereas the experimental group performed better than the control group in terms of the difference between Pre and Post tests results. This result showed than game learning can perform better than traditional style of learning.

In analyzing the difference between Pre-test and Post-test in terms of each items in the test paper, the result can be found as follows:

TABLE V: THE DIFFERENCE BETWEEN PRE AND POST TESTS FOR ITEMS IN THE TEST PAPER (EXPERIMENTAL GROUP)

\begin{tabular}{|l|l|l|l|l|l|}
\hline & \multicolumn{5}{|c|}{ Paired Differences } \\
\cline { 2 - 6 } & Mean & SD & \multicolumn{2}{l|}{$\begin{array}{l}\text { Std. Err } \\
\text { Mean }\end{array}$} & \multicolumn{2}{l|}{$\begin{array}{l}\text { 95\% Confidence } \\
\text { Interval }\end{array}$} \\
\cline { 5 - 7 } & & & & Lower & Upper \\
\hline Pre2A1-Post2A & -8.571 & 3.550 & .6001 & -9.791 & -7.351 \\
Pre2A2-Post2A & -8.000 & 4.058 & .6859 & -9.394 & -6.605 \\
Pre2A3-Post2A & -4.857 & 5.070 & .8571 & -6.599 & -3.115 \\
Pre2A4-Post2A & -5.142 & 5.070 & .8571 & -6.884 & -3.400 \\
Pre2A5-Post2A & -6.285 & 4.902 & .8286 & -7.969 & -4.601 \\
Pre2A6-Post2A & -7.142 & 4.583 & .7747 & -8.717 & -5.568 \\
Pre2A7-Post2A & -3.428 & 4.815 & .8140 & -5.082 & -1.774 \\
Pre2A8-Post2A & -3.428 & 4.815 & .8140 & -5.082 & -1.774 \\
Pre2A9-Post2A & -5.714 & 5.020 & .8487 & -7.439 & -3.989 \\
Pre2A10-Post2A & -2.000 & 4.058 & .6859 & -3.394 & -2.915 \\
\hline
\end{tabular}

PAIRED SAMPLES TEST
\begin{tabular}{|c|c|c|c|}
\hline & $t$ & $d t$ & Sig (2-tailed) \\
\hline Pre2A1-Post2A & -14.283 & 34 & .000 \\
Pre2A2-Post2A & -11.662 & 34 & .000 \\
Pre2A3-Post2A & -5.667 & 34 & .000 \\
Pre2A4-Post2A & -6.000 & 34 & .000 \\
Pre2A5-Post2A & -7.585 & 34 & .000 \\
Pre2A6-Post2A & -9.220 & 34 & .000 \\
Pre2A7-Post2A & -4.212 & 34 & .000 \\
Pre2A8-Post2A & -4.212 & 34 & .000 \\
Pre2A9-Post2A & -6.733 & 34 & .000 \\
Pre2A10-Post2A & -2.915 & 34 & .006 \\
\hline
\end{tabular}

From Table V, the value of $P$ for items 1-9 were 0 and item 10 was 0.006 which were $<0.05$. This showed that the game had a positive effect on enhancing students in all aspects of the test paper.

TABLE VI: THE DIFFERENCE BETWEEN PRE AND POST TESTS FOR ITEMS IN THE TEST PAPER (CONTROL GROUP)

\begin{tabular}{|l|l|l|l|l|l|}
\hline \multirow{2}{*}{} & \multicolumn{5}{|c|}{ PAIRED SAMPLES TEST } \\
\cline { 2 - 6 } & Mean & SD & $\begin{array}{l}\text { Std. Err } \\
\text { Mean }\end{array}$ & \multicolumn{2}{l|}{$\begin{array}{l}\text { 95\% Confidence } \\
\text { Interval }\end{array}$} \\
\cline { 3 - 6 } & & & & Lower & Upper \\
\hline Pre2A1-Post2A & -5.714 & 5.020 & .8487 & -7.439 & -3.989 \\
Pre2A2-Post2A & -4.285 & 5.020 & .8487 & -6.010 & -2.561 \\
Pre2A3-Post2A & -3.714 & 5.469 & .9245 & -5.593 & -1.835 \\
Pre2A4-Post2A & -4.857 & 5.621 & .9501 & -6.788 & -2.926 \\
Pre2A5-Post2A & -3.428 & 4.815 & .8140 & -5.082 & -1.774 \\
Pre2A6-Post2A & -4.857 & 5.070 & .8571 & -6.599 & -3.115 \\
Pre2A7-Post2A & -3.428 & 5.392 & .9114 & -5.280 & -1.576 \\
Pre2A8-Post2A & -3.142 & 5.297 & .8955 & -4.962 & -1.323 \\
Pre2A9-Post2A & -3.428 & 5.392 & .9114 & -5.280 & -1.576 \\
Pre2A10-Post2A & -4.000 & 4.970 & .8401 & -5.707 & -2.292 \\
\hline
\end{tabular}

\begin{tabular}{|c|c|c|c|}
\hline & $t$ & $d t$ & Sig (2-tailed) \\
\hline Pre2A1-Post2A & -6.733 & 34 & .000 \\
Pre2A2-Post2A & -5.050 & 34 & .000 \\
Pre2A3-Post2A & -4.018 & 34 & .000 \\
Pre2A4-Post2A & -5.112 & 34 & .000 \\
Pre2A5-Post2A & -4.212 & 34 & .000 \\
Pre2A6-Post2A & -5.667 & 34 & .000 \\
Pre2A7-Post2A & -3.762 & 34 & .001 \\
Pre2A8-Post2A & -3.510 & 34 & .001 \\
Pre2A9-Post2A & -3.762 & 34 & .001 \\
Pre2A10-Post2A & -4.761 & 34 & .000 \\
\hline
\end{tabular}

From Table VI, the value of $P$ for items $1-10$ were $<0.05$. This showed that the traditional way of learning had a 
positive effect on enhancing students in all aspects of the test paper.

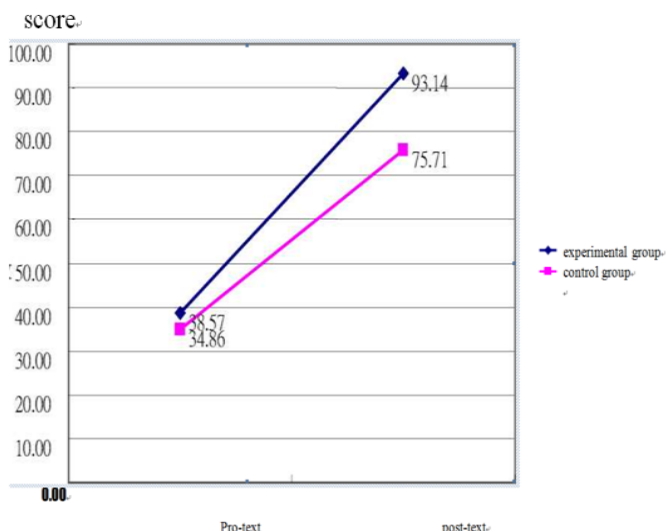

Fig. 3. Variation of scores between experimental and control groups.

\section{B. Difference between Items (Experimental Group)}

Table VII showed the variation of each item between pre and post tests. The lower the $T$ value means the better the post test result. Item 1 and 2 had lowest $T$ value. That means students improved better on item 1 and 2 with game. Those items with relatively higher $T$ values were items 10,7 and 8.This means students' improvement on items 10, 7, 8 were relatively lower with game.

TABLE VII: THE ANALYSIS OF EACH ITEM IN THE TEST PAPER (EXPERIMENTAL GROUP)

\begin{tabular}{|l|l|l|l|}
\hline Items & $\begin{array}{l}\text { Pre Test } \\
\text { Frequency } \\
\text { (Percentage) }\end{array}$ & $\begin{array}{l}\text { Post Test } \\
\text { Frequency } \\
\text { (Percentage) }\end{array}$ & $T$ Value \\
\hline Item 1 & $50(14.3 \%)$ & $350(100 \%)$ & -14.283 \\
\hline Item 2 & $50(14.3 \%)$ & $330(94.3 \%)$ & -11.662 \\
\hline Item 3 & $180(51.4 \%)$ & $350(100 \%)$ & -5.667 \\
\hline Item 4 & $170(48.6 \%)$ & $350(100 \%)$ & -6.000 \\
\hline Item 5 & $10(2.9 \%)$ & $230(65.7 \%)$ & -7.585 \\
\hline Item 6 & $50(14.3 \%)$ & $300(85.7 \%)$ & -9.220 \\
\hline Item 7 & $230(65.7 \%)$ & $350(100 \%)$ & -4.212 \\
\hline Item 8 & $220(62.9 \%)$ & $340(97.1 \%)$ & -4.212 \\
\hline Item 9 & $120(34.3 \%)$ & $320(91.4 \%)$ & -6.733 \\
\hline Item 10 & $270(77.1 \%)$ & $340(97.1 \%)$ & -2.915 \\
\hline
\end{tabular}

Before game learning, not many students could have correct answer on items 1 and 2 (only $14.3 \%$ of students obtained scores) but comparatively more students answered correctly on item $7,8,10(65.7 \%, 62.9 \%, 77.1 \%$ of students respectively obtained scores). After the game, over $90 \%$ of the students answered correctly of items 1, 2, 7, 8, 10.

Item 1 and 2 were about the use of Rectangular drawing tool to make the picture frames. These could be difficult to those who did not have experience of computer drawings. While playing with the game, students had many practice in using "Rectangular Tool" to create different shapes, therefore they improved dramatically in the post test. Item 7 and 8 were related to the use of "Stucco Tool" which was a free style drawing tool. Since students use pencils daily, the function of "Stucco Tool" was very similar to pencils. Students were relatively easily to handle this tool under their natural reaction. Therefore, they had good result in pre-test. After the game, again, students had many opportunities to practice with this tool; hence they performed well on item 7, 8, 10 in post-test.
For item 5, the result for pre test was comparatively lower than other items. Since this item required students to use "Shift" key to draw the circle, this involved not just the use of the drawing tools on the problem, but involving students to memories and practice it, which was difficult for students to achieve it under the natural reaction. After the use of game instruction, students had certain improvement in this item.

\section{Difference between Items (Control Group)}

Table VIII showed the variation of each item between pre and post tests for control group. With traditional style of learning, Item 1 and 6 had lowest $T$ value. That means, students had relatively highest improvement on item 1 and 6 . Items 7-9 had relatively higher $T$ values. This means students' improvement on items 7-9 were relatively lower.

Since there were not many students could answer correctly on items 1 and 6 (only $17.1 \%$ of students obtained scores) in pre-test, therefore, after traditional style of learning, the percentage increased to $74.3 \%$ and $64.7 \%$ respectively.

TABLE VIII: THE ANALYSIS OF EACH ITEM IN THE TEST PAPER (CONTROL GROUP)

\begin{tabular}{|l|l|l|l|}
\hline Items & $\begin{array}{l}\text { Pre Test } \\
\text { Frequency } \\
\text { (Percentage) }\end{array}$ & $\begin{array}{l}\text { Post Test } \\
\text { Frequency } \\
\text { (Percentage) }\end{array}$ & $T$ Value \\
\hline Item 1 & $60(17.1 \%)$ & $260(74.3 \%)$ & -6.733 \\
\hline Item 2 & $90(25.7 \%)$ & $240(68.6 \%)$ & -5.050 \\
\hline Item 3 & $190(54.3 \%)$ & $320(91.4 \%)$ & -4.018 \\
\hline Item 4 & $170(48.6 \%)$ & $340(97.1 \%)$ & -5.112 \\
\hline Item 5 & $10(2.9 \%)$ & $130(37.1 \%)$ & -4.212 \\
\hline Item 6 & $60(17.1 \%)$ & $230(65.7 \%)$ & -5.667 \\
\hline Item 7 & $150(42.9 \%)$ & $270(77.1 \%)$ & -3.762 \\
\hline Item 8 & $150(42.9 \%)$ & $260(74.3 \%)$ & -3.510 \\
\hline Item 9 & $160(45.7 \%)$ & $280(80 \%)$ & -3.762 \\
\hline Item 10 & $180(51.4 \%)$ & $320(91.4 \%)$ & -4.761 \\
\hline
\end{tabular}

Item 7 and 8 were related to the use of "Stucco Tool", the reasons for control group to have good results in this item could be similar to experimental group.

As in experimental group, the pre-test result for item 5 was comparatively lower than other items. Although the result of the post test was improved in the post test, the increment was not as much as experimental group.

\section{Analysis}

In comparing the pre-tests result for experimental and control groups, similar trend was obtained for different items in the test paper. That means the prior knowledge for both groups were similar.

In comparing the $T$ values for both groups, experimental group performed better on all items in the test paper. Especially for items with high difficulties (item 5, 6), the experimental group improved more significant than control group.

In this experiment, experimental group succeeded in every aspects of the test paper. The game can improve the performance of students in different type of questions.

\section{CONCLUSION}

Based on the results from pre and post-tests, the majority of students performed better. It is no doubt that the both game and traditional learning style can both enhance students' 
learning ability.

In comparing the results between both groups, students who learn from game performed better than traditional learning style. Moreover, no matter which type of questions in the test paper, game learners performed better than traditional learners.

The successful in game learners can be partially be explained by the audio and vision stimuli of the game which can promote learning in dual channels [19]-[21].

Classroom teaching is the pivotal factor affecting students' learning. The visual and auditory stimuli from computer games intrinsically motivate students to play. With suitable amount of learning ingredient added to the games, games can be very effective teaching tools in classroom. In compare with the "traditional teaching" approach, students in the classroom quietly listening to the teacher's explanations, assimilate, and then carried out the work under the guidance of teachers. However students may somehow feel "dry" or "dull" and rarely as effective as they might be in the motivating students, and this often causes real problems in getting our students to learn.

With the assistance of games, teachers may gain their expected teaching effectively especially if games can be combined with other the teaching methods. By taking advantages with the visual and audio stimulation of games, students can learn in an enjoyable learning environment.

\section{REFERENCES}

[1] J. P. Gee, Situated Language and Learning: A Critique of Traditional Schooling, Routledge, 2004

[2] J. P. Gee, "What Video Games Have to Teach Us about Learning and Literacy," Palgrave Macmillan, 2004

[3] R. Koster, A Theory of Fun for Game Design, Paraglyph Press, 2005.

[4] M. Prensky, Digital Game-Based Learning, R. R. Donnelley and Sons Company, 2001.

[5] H. Kennedy, "Computer games liven up military recruiting, training," National Defense, November, 2002.

[6] Federation of American Scientists, Harnessing the power of video games for learning, Report from summit of Educational games, 2006

[7] R. C. Schank, "What we learn when we learn by doing. The Institute for Learning Sciences, "Technical Report, vol. 60, no. 1, 1994.

[8] A. McFarlane, A. Sparrowhawk, and Y. Heald, "Report on the educational use of games: An exploration by TEEM of the contribution which games can make to the education process," Cambridge, 2002.

[9] R. Rosas, M. Nussbaum et al., "Design and assessment of educational video games for first and second grade students," Computers \& Education, vol. 40, pp. 71-94, 2003.
[10] C. Aldrich, Simulations and the future of learning: An innovative (and perhaps revolutionary) approach to e-learning, San Francisco: Pfeiffer, 2004.

[11] J. Steven, "Everything Bad is Good for You," How Today's Popular Culture Is Actually Making Us Smarter, ISBN: 978-1-59448-194-9, 2005.

[12] M. Habgood, S. Ainsworth, and S. Benford, "The educational and motivational content of digital games made by children," presented at CAL 05: Virtual Learning, Bristol, UK, 2005.

[13] K. L. Howland, J. Good, and J. Robertson, "Script Cards: A Visual Programming Language for Games Authoring by Young People," in Proc. IEEE symposium on visual languages and human-centric computing, Brighton, UK, September 2006.

[14] C. Kelleher and R. Pausch, "Lessons Learned from Designing a Programming System to Support Middle School Girls Creating Animated Stories," in Proc. IEEE Symposium on Visual Languages and Human-Centric Computing, 2006.

[15] K. Perciles. (2007). Game2Learn. [Online]. Available: http://kpericles.edublogs.org/

[16] J. Robertson and J. Good, "Story creation in virtual game worlds," Communications of the ACM, vol. 48, pp. 61-65, 2005.

[17] J. Robertson and J. Good, "Children's narrative development through computer game authoring Technology Trends," vol. 49, no. 5, 2005.

[18] D. Szafron, M. Carbonaro et al., "Writing Interactive Stories in the Classroom," Interactive Multimedia Electronic Journal of Computer-Enhanced Learning, vol. 7, no. 1, 2005.

[19] R. E. Mayer, Multimedia learning, New York: Cambridge University Press, 2001.

[20] R. E. Mayer and R. Moreno, “A Cognitive Theory of Multimedia Learning: Implications for Design Principles,” 1998.

[21] R. Moreno and R. Mayer, "Cognitive principles of multimedia learning: The role of modality and contiguity," Journal of Educational Psychology, vol. 91, pp. 358-368, 1999.

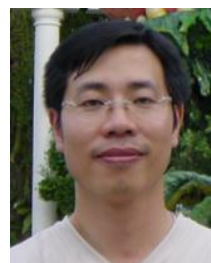

Chun Wai Andy Fan is currently working in University of Macau (UMAC) as an assistant professor in Faculty of Education and program coordinator for Postgraduate Certificate of Education. Andy is also the chapter chair of IEEE Education Society Macao Section. Before joining UMAC, he was a lecturer in the Department of Information and Applied Technology in Hong Kong Institute of Education (HKIED) and a visiting lecturer in Glasgow Caledonian University (UK).

Andy 's general research interests includes Information Technology in Education, Computer Assisted Learning, Intelligent Tutoring System, Web-based Learning, and Online Testing. The selected current publications include "Research on IT in Education and IT facilities in Macao Schools" University of Macau Press; "Research on the Applications of Information Technology in Education in Macao Schools".

Andy is the long term member of IEEE and AACE. He was awarded "The Outstanding Leadership" from IEEE to acknowledge the contributions that leads to significant growth, program improvement and membership development for the society and "The Distinguished Contribution" from IEEE to acknowledge the work to the IEEE Education Society Chapter and Regional Activity Committee. 